\title{
THE IMPLEMENTATION OF INQUIRY-BASED LEARNING STRATEGY TO ENHANCE STUDENTS' WRITING ABILITY IN DESCRIPTIVE TEXT
}

\author{
Imansyah, M.Pd, Terasne, M.Pd.B.I and Khorida Yan Hartina \\ English Department, Faculty of Language Education and Arts \\ Mataram Institute of Teacher Training and Education \\ Email: imansyah022@gmail.com
}

\begin{abstract}
This research was aimed at knowing whether Inquiry-Based Learning strategy enhanced students' writing ability in descriptive text or not. The research was a classroom action research. The data collected through quantitative and qualitative ways. Quantitative data was gained from the result of pre-test and post-test from writing test. Meanwhile, qualitative data was gained from the result of observation sheets toward students' and teachers activity. The instrument used by the researcher were test and observation sheet. The finding of the research shows that the strategy can improve the students' writing ability in descriptive text. the improvement can be seen from the mean score of students from pre-test, post-test one, and post-test two. The mean score of pre-test was $69.5(35 \%)$, there were seven students who passed the minimum passing grade, in the post-test one, $72.2(60 \%)$, twelve students passed the minimum passing grade and in the post-test two, $78.25(85 \%)$, seventeen students passed the minimum passing grade (KKM) from twenty students.
\end{abstract}

\section{Key Words: Inquiry-Based Learning}

\section{INTRODUCTION}

\section{Background of Study}

Writing is one of an important ability that must be learned by the learners beside of other skills like speaking, reading, and listening. The activity of writing was gave chance to learners to express their personalities and their ideas through written text. In getting the success of writing, the students have to master some elements of writing such as: content, organization, vocabulary, language use, and mechanics. Where it would help the learners in writing.

But, by some people writing could be called as the one of difficult ability to be learned by the learner especially in English because writing involves a complex cognitive activity, as defined by Heaton (1988: 135) stated that writing skill is complex and sometimes difficult to teach, requiring to master the grammatical and rhetorical devices but also conceptual and judgmental elements. It means that writing is not only about arranging the words into complete sentences or paragraph but also writing ability require the writers to follow the rule of grammar, organization, spelling, vocabulary and should have the concept in writing.

Based on the researchers' observation at SMAN 2 Pujut. The researcher founds that there were some problems faced by the students in writing. First, they had low ability in writing English, their writing was far 
from what expected, the fact that they did not know how to begin to write a simple descriptive text. Second, they felt difficult to find out the idea to write. Third, the student wrote paragraph in not clear and not detail information. Fourth, their paragraphs had many grammatical inaccuracies. The last problem was they did not participate much in the writing class.

Dealing with some problems above, it was necessary to explore a strategy which is expected to improve students' ability in writing especially in writing descriptive text during teaching and learning process. One of the strategy hopefully might improve students' writing ability in descriptive text is that Inquiry-Based Learning strategy. The researcher tried to solve those problems in writing ability by applying InquiryBased Learning entitled "The Implementation of Inquiry-Based Learning Strategy to Enhance Students' Writing Ability in Descriptive Text"

\section{Statement of Problem}

Based on the background above, statement of problem stated that; How does Inquiry-Based Learning strategy enhance the students' writing ability in descriptive text at the tenth grade of SMAN 2 Pujut in academic year 2017/2018?.

\section{Objective of Study}

In line with the statement of problem above, this study was intended to implementing Inquiry-Based Learning strategy to enhance the students' writing ability in descriptive text at the tenth grade of SMAN 2 Pujut in academic year 2017/2018.

\section{Limitation of Study}

This study was limited to implementing Inquiry-Based Learning strategy to enhance the students' writing ability in descriptive text at the tenth grade of SMAN 2 Pujut in academic year 2017/2018.

\section{Significances of Study}

The significances of the study is both of theoretically and practically elaborated as follow:

1. The Theoretical Significance

a. For the Next Researcher

This study might be useful for the researchers as their references in conducting their research in the next future.

b. For the Reader

The result of this study could give important information about new strategy in teaching writing.

2. The Practical Significant

a. For the Teacher

The result of this study is expected to enriches their teaching strategies in teaching writing especially in descriptive text that can be applied in the classroom.

b. For the students

For the students, by using Inquiry-Based Learning strategy is expected to help them enhance their writing ability especially in descriptive text.

\section{Definition of Writing}

Writing as one of important ability that must be mastered by learners, writing could be defined as communication tool to interact to each other through written text, a way of 
sharing information, thoughts or ideas. According to Weigle (2002: 1) states that writing has also become more important as tenets of communicative language teaching that is, teaching language as a system of communication rather than as an object of the study have taken hold in both second and foreign language setting. Furthermore, Harmer (1998: 79) states that the reason for teaching writing to students of English as a foreign language include reinforcement, language development, learning style, and most importantly writing is a skill in its own right.

From some description above, it can be concluded that writing is become crucial thing to teach to students in which through writing students can develop their language, and also the process of writing is more than a matter of elaborate or arrange the thought or ideas into sentences or text in written form but also writing creates a communicative language between the writer and the reader. It creates a permanent and visible record of ideas for others to read.

\section{Indicators of Writing}

Writing skills have five indicators based on Heaton (1988: 146) they are content, organize, vocabulary, language use and mechanics.

a. Content is the ability to think creatively and develop thoughts, excluding all irrelevant information.

b. Organize is the total of all the choices a writer makes concerning words and their arrangements. In this sense style may be good or bad-good if the choices are appropriate to the writer's purpose, bad if they are not.

c. Vocabulary is a branching process rather than a linear one. Words are not learning mechanically, as little packets of meaning, but associatively.

d. Language use designates rules of a less basic and binding sort, concerning how we should use the language in situations.

e. Mechanics is consisting of spelling and punctuation that needed to write to avoid from an error or mistake in meaning.

\section{Definition of Descriptive Text}

Description is writing about characteristics features of a particular thing, describe about how they look like. According to Oshima and Hogue (1997: 50) Descriptive writing appeals to the senses, so it tells how something looks, feels, smells, tastes, and/or sounds. In addition, a good description is like "a word picture"; the reader can imagine the object, place, or person in his or her mind.

\section{Definition of Inquiry-Based Learning}

According to Caswell \& La Brie (2017: 3) Inquiry-Based Learning is an instructional practice where students explore content by posing, investigating, and answering questions. Students are at the center of the learning experience and take ownership of their own learning. They often work independently and in small collaborative groups. Meaning that, Inquiry-Based Learning is a strategy which put the students as a center of learning in which they will do the observation or investigation towards the real object provided by teacher they will outline it after all they will discussing with their groups.

\section{A model for inquiry}


According to Alberta Learning (2004: 10) there are some phase of inquiry model which conducted when teaching learning process.

a. Planning phase

At this phase involves identify a topic area for inquiry, identify possible information sources, identify audience and presentation format, establish evaluation criteria, outline a plan for inquiry.

b. Retrieving

This phase involves develop an information retrieval plan, locate and collect resources, select relevant information, evaluate information, review and revise the plan for inquiry.

c. Processing

The inquirers will establish a focus for inquiry, choose pertinent information, record information, make connections and inferences, review and revise the plan for inquiry.

d. Creating

At this phase the inquirers will organize information, create a product, think about the audience, revise and edit, review and revise the plan for inquiry.

e. Sharing

Communicate with the audience, present new understanding, demonstrate appropriate audience behaviour.

f. Evaluating

At this phase the inquirers will evaluate the product,evaluate the inquiry process and inquiry plan, review and revise personal inquiry model, transfer learning to new situation/beyond school.

\section{RESEARCH METHOD}

The design of this research was classified as collaborative Classroom Action Research (CAR). According to R. B. Burns in Burns (1999: 30) action research is the application of fact finding to practical problem solving in a social situation with a view to improving the quality of action within it, involving the collaboration and co-operative of researchers, practitioners. In this research, the researcher act as an observer and collaborate with English teacher as an implementer. The researcher used the classroom action research Kemmis and Mc Taggart's model in Burns (1999: 32) that consists of four steps: plan, act, observe and reflect. The figure as below:

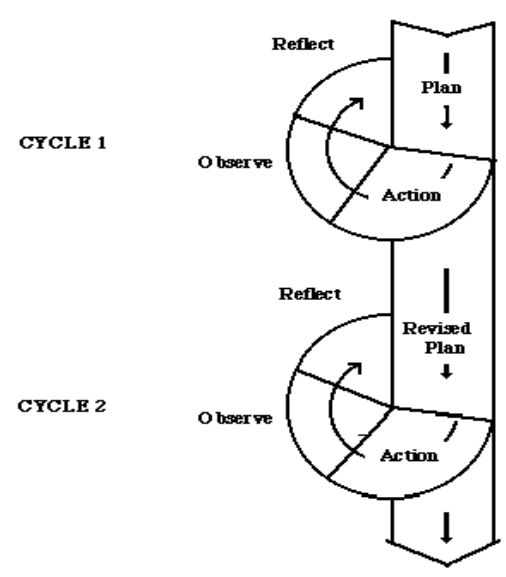

There were some procedures that were used in this research such as consist of preliminary study, planning, acting, observing, and reflecting.

\section{Subject and Object of the Research}

The subject of this research was the students of class X IPS2 of SMAN 2 Pujut in the academic year of 2017/2018. There were 20 students in this class, 13 male and 7 female students. The object of this research was the implementation of Inquiry-Based Learning strategy to 
enhance students' writing ability in descriptive text.

\section{Instrument of the Research}

The instrument that used in this research was test and observation sheet. The test was in written test the students wrote text in form of descriptive text. Furthermore, the researcher used observation sheet to observe the process of teaching and learning in the classroom.

\section{Techniques of Data Collection}

The techniques of data collection were used in this research namely;

1. Test

The test used in this research was written test which conducted in pre-test and post-test. The pre-test was conducted before implementing Inquiry-Based Learning strategy. It was to measure students' writing comprehension at first. Then, the post-test was conducted after using Inquiry-Based Learning strategy.

2. Observation sheets

The researcher used the observation sheet to know what happened during teaching and learning process. In this research, the researcher acts as the observer, and collaborate with the English teacher. The researcher used the observation sheets that consist of students' activity in teaching and learning process through Inquiry-Based Learning strategy, and teacher's activity during teaching and learning process. After collecting the data, the researcher analyze the data through quantitative and qualitative way.

\section{Techniques of Data Analysis}

Techniques of data analysis is the way that used by the researcher in analyzing the data those were quantitative and qualitative.

1. Quantitative way

In quantitative data the researcher compared the students' average score of pre-test and post-test. This research was considered success when they have achieved the indicator of success of writing ability with the score of school minimum passing grade or called KKM (Kriteria Ketuntasan Minimum) was 75.

In this classroom action research, the quantitative data was the result of students' achievement from the test (pretest and post-test). The test can be counted as follows:

a. The average of students' test result was counted by using the following formula:

$$
\overline{\mathrm{X}}=\frac{\sum f \mathrm{x}}{N}
$$

Where:

$\bar{X} \quad=$ The mean score of the students

$\sum f \mathrm{x}=$ The individual score

$N \quad=$ The total number of students

(Miller, 2005: 132)

b. The improvement students' achievement was counted by using the following formula:

$$
P=\frac{F}{\mathrm{~N}} \times 100 \%
$$

Where:

$\mathrm{P} \quad=$ The class persentage

$\mathrm{F} \quad=$ Total persentage score

$\mathrm{N}=$ The total number of the students.

2. Qualitative way

The qualitative data was the description on the process of teaching and learning using Inquiry-Based Learning to improve students' writing ability in descriptive text from the planning to acting and the observation and also to the reflecting process. 


\section{RESEARCH FINDINGS AND DISCUSSION}

This research was preceded by the result of preliminary study conducted before implementing the Inquiry-Based Learning strategy and followed by the result of post-test 1 and post-test 2. Based on the findings showed that:

a. The result of pre-test

Table 01.Result of pre-test

\begin{tabular}{|l|l|c|c|}
\hline No & Name & $\begin{array}{c}\text { Score of } \\
\text { Writing } \\
\text { Test }\end{array}$ & \\
\hline 1 & NI & 63 & Failed \\
\hline 2 & HS & 75 & Pass \\
\hline 3 & SN & 66 & Failed \\
\hline 4 & SA & 60 & Failed \\
\hline 5 & LAI & 63 & Failed \\
\hline 6 & MDI & 66 & Failed \\
\hline 7 & MAJ & 65 & Failed \\
\hline 8 & ZR & 70 & Failed \\
\hline 9 & RS & 65 & Failed \\
\hline 10 & NPA & 77 & Pass \\
\hline 11 & OKP & 70 & Failed \\
\hline 12 & FFR & 75 & Pass \\
\hline 13 & LWA & 75 & Pass \\
\hline 14 & DI & 80 & Pass \\
\hline 15 & EI & 65 & Failed \\
\hline 16 & IDW & 70 & Failed \\
\hline 17 & GII & 75 & Pass \\
\hline 18 & ISS & 75 & Pass \\
\hline 19 & AAI & 65 & Failed \\
\hline 20 & JAI & 70 & Failed \\
\hline & $\Sigma$ & 1.390 & \\
\hline & & & \\
\hline & & & \\
\hline
\end{tabular}

The result of pre-test showed that the highest score was $80(5 \%)$ and the lowest score was $60(5 \%)$. The mean score was 69.5. From the data above found that there were seven students who pass the minimum passing grade or KKM 75, the rest of them were under the KKM. b. The Result of Writing Test Cycle One Table 02. Result of Writing Test Cycle1

\begin{tabular}{|l|l|c|c|}
\hline No & Name & $\begin{array}{c}\text { Score of } \\
\text { Writing } \\
\text { Test }\end{array}$ & Grade \\
\hline 1 & NI & 75 & Pass \\
\hline 2 & HS & 75 & Pass \\
\hline 3 & SN & 66 & Failed \\
\hline 4 & SA & 75 & Pass \\
\hline 5 & LAI & 60 & Failed \\
\hline 6 & MDI & 66 & Failed \\
\hline 7 & MAJ & 75 & Pass \\
\hline 8 & ZR & 70 & Failed \\
\hline 9 & RS & 65 & Failed \\
\hline 10 & NPA & 80 & Pass \\
\hline 11 & OKP & 70 & Failed \\
\hline 12 & FFR & 75 & Pass \\
\hline 13 & PAS & 75 & Pass \\
\hline 14 & DI & 85 & Pass \\
\hline 15 & EI & 65 & Failed \\
\hline 16 & IDW & 75 & Pass \\
\hline 17 & GII & 75 & Pass \\
\hline 18 & ISS & 75 & Pass \\
\hline 19 & AAI & 65 & Failed \\
\hline 20 & JAI & 77 & Pass \\
\hline & $\Sigma$ & & 1.444 \\
\hline
\end{tabular}

The mean score of Post-test 1 was

$$
\mathrm{X}=\frac{\sum f \overline{\mathrm{x}}}{N}
$$

Notation $\quad \sum f \mathrm{x}=1.444$

$$
\mathrm{N}=20
$$

Calculation $\bar{X}=\frac{1.444}{20}=72.2$

The percentage of students' score who pass the criteria of success (75):

$P=60 \%$

$$
\begin{aligned}
& P=\frac{F}{\mathrm{~N}} \times 100 \% \\
& P=\frac{12}{20} \times 100 \%
\end{aligned}
$$


Based on the calculation above the mean score of writing test in cycle one was 72.2. The highest score was 85 and the lowest score was 60 . The percentage of students was $60 \%$ there were 12 students passed the criteria of success out of the 20 students, while the rest of them were 8 students or $40 \%$ failed.

c. The Result of Writing Test Cycle Two

Table 03. Result of Writing Test

$$
\text { Cycle } 2
$$

The mean score of pre-test was

$$
\overline{\mathrm{X}}=\frac{\sum f \mathrm{x}}{N}
$$

Notation $\quad \sum f \mathrm{x}=1.565$

Calculation $\quad \frac{N}{X}=\frac{1.565}{20}=78.25$

The persentage of students' score who pass the criteria of success or KKM (75):

$$
\begin{gathered}
P=\frac{F}{\mathrm{~N}} \times 100 \% \\
P=\frac{17}{20} \times 100 \%
\end{gathered}
$$

$P=85 \%$

\begin{tabular}{|l|l|c|c|}
\hline No & $\begin{array}{c}\text { Nam } \\
\text { e }\end{array}$ & $\begin{array}{c}\text { Students' } \\
\text { Writing } \\
\text { Score }\end{array}$ & Score \\
\hline 1 & NI & 85 & Pass \\
\hline 2 & HS & 85 & Pass \\
\hline 3 & SN & 75 & Pass \\
\hline 4 & SA & 80 & Pass \\
\hline 5 & LAI & 75 & Pass \\
\hline 6 & MDI & 80 & Pass \\
\hline 7 & MAJ & 75 & Pass \\
\hline 8 & ZR & 80 & Pass \\
\hline 9 & RS & 70 & Failed \\
\hline 10 & NPA & 90 & Pass \\
\hline 11 & OKP & 70 & Failed \\
\hline 12 & AA & 75 & Pass \\
\hline 13 & PAS & 75 & Pass \\
\hline 14 & DI & 85 & Pass \\
\hline 15 & EI & 65 & Failed \\
\hline 16 & IDW & 85 & Pass \\
\hline
\end{tabular}

\begin{tabular}{|l|l|l|l|}
\hline 17 & GI & 75 & Pass \\
\hline 18 & ISS & 75 & Pass \\
\hline 19 & AAI & 80 & Pass \\
\hline 20 & JAI & 85 & Pass \\
\hline \multicolumn{2}{|c|}{$\Sigma$} & & 1.565 \\
\hline
\end{tabular}

From the calculation above the mean score of writing test in cycle two was 78.25. The highest score was 90 and the lowest score was 70 . The percentage was $85 \%$ there were 17 students who passed the criteria of success and 3 of them was failed.

d. The Result of Observation Sheet

During the process of teaching and learning in the classroom, the result of observation sheet was filled by the researcher and the collaborator English teacher at knowing the the implementation of inquiry-based learning strategy in enhancing students' writing ability in descriptive text. this research was conducted in two cycles.

1. The result of observation sheet in cycle one

The result of observation sheet towards students' activities showed that most of students did not pay attention to teacher's explanation, caused by the teacher most of the time used English, the students paragraph still had some mistakes in term of content, organization, and language use, they felt shy to ask when they did not understand about the material, the situation of classroom was crowded, and they got difficulty in expressing their ideas especially in English.

The observation sheet of teacher activities showed that the teacher unable to handle the students in the class, the teacher got difficulty when the students did not understand what he talked about because mostly teacher was spoken in 
English, and the teacher did not actively monitor the students.

2. The result of observation sheet in cycle two

The result of observation sheet towards students' activities showed that most of students paid attention to teacher's explanation because the teacher used both English and Indonesian language, the teacher able to handle the students activities during teaching and learning process.

The result of observation sheet towards teacher's activities showed that the teacher was able to handle the class and decided to use both English and Indonesian language, and actively monitor students by walking to each group to correct or give some comments of the students' writing.

Furthermore, after the researcher analyzed and compared the result of the observation sheet from the first cycle to the second cycle, it could be conclude that the students' writing ability in descriptive text was improve and became more active in learning in the classroom.

\section{DISCUSSION}

After conducting the research by using inquiry-based learning strategy on the first meeting, the researcher found that several of students still seemed confuse and difficult to write or find out the ideas and less pay attention to teacher's explanation. Moreover, the result of the students' mean score on the first cycle did not meet the criteria of success. Therefore, the researcher and the collaborator decided together to conduct the second cycle.
Then on cycle two, the activities in this cycle was done better than the cycle one. The students involved actively in learning process and paid attention to the teacher's explanation. They looked enthusiastic to do the tasks by using this strategy and they followed every instruction from their teacher. Through Inquiry-Based Learning strategy involved students work within a group and do the investigation directly toward the object that given by the teacher.

Based on the result of data analysis on cycle 1, it was found the students' highest score was 85 and the lowest score was 60. Generally, in the cycle 1 there were 7 students who passed the test beyond the criteria of success was 75 based on the school agreement. And the rest of them 13 students were failed on the test or still under the criteria of success. Meanwhile, on the cycle 2 the students' highest score was 90 and the lowest score was 65 . In this case, the students' progress showed that the students who achieved the criteria of success increased from 12 students $(60 \%)$ on cycle 1 to 17 students (85\%) in cycle two. From the result of cycle 1 and the cycle 2, it was showed that the InquiryBased Learning strategy could enhance students' writing ability in descriptive text.

In addition, related to the relevant studi in this research, there were some differences and the similarities found those are, based on the research conducted by Nurtalina (2013). It has the same strategy to use in improving the writing ability of the students that was Inquiry-Based Learning strategy. But this research has difference in the use of research design, this research was used 
the classroom action research, while Nutralina's research used experimental research with experimental group and control group. The result of both these researchs show that the use of InquiryBased Learning strategy improving the writing ability of the students.

\section{CONCLUSION AND SUGGESTION}

After analyzing the data, the researcher could conclude that the implementation of Inquiry-Based Learning strategy was able to enhance students' writing ability in descriptive text at the tenth grade of SMAN 2 Pujut. The students' achievement in writing descriptive text was better after implementing the Inquiry-Based Learning strategy. It was proven by the result of the mean score at cycle 1 was $72.2(60 \%)$ and cycle 2 was 78.25 (85\%). There was a progress, but the result of cycle 1 was not met the criteria of success yet. Then, the result of observation sheets on cycle one showed that not all of the students involved actively in teaching and learning process.

On cycle 2 was found that there were 17 students or $85 \%$ of 20 students who passed the criteria of success or KKM. In conclusion, by using InquiryBased Learning strategy was able to enhance students' writing ability in descriptive text, through this strategy was gave chance for students to work together within a group and do the investigation directly toward the object that given by the teacher. And this strategy was called successful based on the findings of the research.

Based on the research finding, Inquiry-Based Learning strategy was able to increase students' writing in descriptive text, this strategy could be the alternative to overcome the students problem in learning writing. So, the researcher would like to contribute some suggestions especially for:

1. For the Teacher

Inquiry-Based Learning would be helpful to increase students' writing, so the teacher needs to maintain using Inquiry-Based Learning strategy in the next new academic year.

2. For School

The principle of SMAN 2 Pujut must be considered this strategy to be applied by other teacher with other subject not only English teacher because this strategy is dealing with observation directly to the object.

\section{REFERENCES}

Alberta Education. 2004. Focus on Inquiry: A Teacher's Guide to Implementing Inquiry-Based Learning. Canada: Learning Resources Center.

Burns, A. 1999. Collaborative Action Research for English Language Teacher. United Kingdom: Cambridge University Press.

Caswell, C. J \& La Brie, D. J. 2017. Inquiry based learning from the learner's point of view: a teacher candidate's success story. Claremont College Library: Journal of humanistic mathematics. Vol, 7, Issue 2.

Harmer. 1998. How to Teach English An Introduction To The Practice of English Language Teaching. England: Addison Wesley Longman. 
Heaton, J. B. 1988. Writing English Language Test. New York: Longman Group UK.

Miller, S. 2005. Experimental Design and Statistic $2^{\text {nd }}$ Edition. London: Routledge.

Nurtalina. 2013. The Effect Of InquiryBased Learning Strategy In The Writing Ability of The Eighth Grade Students of SMP Negeri 1 Prambanan Klaten In The Academic Year of 2012/2013. Yogtakarta: Unpublished Thesis. YogyakartaState University.

Oshima, A \& Hogue, A 1997. Introduction to Academic Writing (2 ${ }^{\text {nd }}$ Edition). New York: Addison Wesley Longman.

Weigle, S. C. 2012. Assessing Writing. New York: Cambridge University Press. 